This is an Open Access article under the CC BY-SA license (http://creativecommons.org/licenses/by-sa/4.0/)

\title{
PENGARUH RELAKSASI OTOT PROGRESIF TERHADAP PENURUNAN ANSIETAS DAN PENINGKATAN KUALITAS TIDUR PASIEN NEUROSA DI WILAYAH KERJA PUSKESMAS KEPANJEN KIDUL KOTA BLITAR (The Effect of Progressive Muscle Relaxation on the Anxiety Decrease and Improving Quality of Sleep Neurosa Patients in Health Center Area Kepanjen Kidul Blitar City)
}

\author{
Nawang Wulandari ${ }^{1}$, Titin Andri Wihastuti ${ }^{2}$ Lilik Supriati $^{2}$ \\ ${ }^{1}$ Mahasiswa Program Studi Magister Keperawatan Fakultas Kedokteran Universitas Brawijaya \\ ${ }^{2}$ Pengajar Program Magister Keperawatan Fakultas Kedokteran Universitas Brawijaya \\ email: na_wul23@yahoo.co.id
}

\begin{abstract}
Neurosa a psychic reaction with typical anxiety where clients are in fear that unconsciously displayed in various forms of behavior. Anxiety can leads physical imbalance such as increased blood pressure, insomnia, muscle tension and palpitations. Muscle tension and sleep difficulties are often experienced anxiety response. Some psychotherapy can be given to clients of anxiety one of which is progressive muscle relaxation therapy. The aims of this study was to determine the effect of progressive muscle relaxation therapy to decrease anxiety and improve the quality of sleep in patients neurosa in Health Center Area Kepanjen Kidul Blitar. Research design was quasy experimental Pre-Post Test With Control Group with purposive sampling. Number of samples 26 respondents were divided into control and treatment groups. Collecting data using questionnaires that have tested the validity and reliability. Results of analysis of anxiety and sleep quality was obtained $p<0.05$ in the treatment group and control before and after treatment, the difference in scores of anxiety and sleep quality of patients neurosa between the treatment group and the control group after a given intervention $p<0.05$. There is no correlation between the anxiety with the quality of sleep with $p>0.05$. Therapy progressive muscle relaxation and deep breathing therapy can be used to reduce anxiety and improve sleep quality in patients neurosa.
\end{abstract}

Keywords: Progressive Muscle Relaxation, Anxiety, Sleep Quality, Neurosa

\begin{abstract}
Abstrak: Neurosa merupakan reaksi psikis dengan ciri khas kecemasan dimana klien berada dalam ketakutan yang secara tidak sadar ditampilkan dalam berbagai bentuk tingkah laku. Kecemasan dapat menyebabkan ketidakseimbangan fisik misalnya peningkatan tekanan darah, insomnia, ketegangan otot dan palpitasi. Ketegangan otot dan kesulitan tidur adalah respon kecemasan yang sering dialami. Beberapa psikoterapi dapat diberikan pada klien kecemasan salah satunya terapi relaksasi otot progresif. Penelitian ini bertujuan untuk mengetahui pengaruh terapi relaksasi otot progresif terhadap penurunan kecemasan dan peningkatan kualitas tidur pada pasien neurosa di Wilayah Kerja Puskesmas Kepanjen Kidul Kota Blitar. Desain penelitian Quasy Eksperimental Pre-Post Test With Control Group dengan purposive sampling. Jumlah sampel 26 responden dibagi menjadi kelompok kontrol dan perlakuan. Pengumpulan data menggunakan kuesioner yang telah dilakukan uji validitas dan realibilitas. Hasil analisis kecemasan dan kualitas tidur didapatkan $\mathrm{p}<0,05$ pada kelompok perlakuan dan kontrol sebelum dan sesudah diberikan terapi, perbedaan skor kecemasan dan kualitas tidur pasien neurosa antara kelompok perlakuan dan kelompok kontrol setelah diberikan intervensi $p<0,05$. Tidak ada hubungan antara kecemasan dengan kualitas tidur dengan $p>0,05$. Terapi relaksasi otot progresif dan terapi nafas dalam dapat digunakan untuk menurunkan kecemasan dan meningkatkan kualitas tidur pada pasien neurosa.
\end{abstract}

Kata kunci: Relaksasi Otot Progresif, Kecemasan, Kualitas Tidur, Neurosa 
Neurosa adalah gangguan mental dimana kondisi psikis klien berada dalam ketakutan dan kecemasan yang kronis tetapi daya nilai realitasnya tidak terganggu (Arifin, 2009). Pada neurosa, individu melakukan tekanan-tekanan terhadap emosi negatif yang dirasakan akibat kesalahan yang telah dilakukan ke alam bawah sadar, dimana hal tersebut akan berpengaruh terhadap perasaan, pikiran, tingkah laku dan kesehatan tubuh seseorang yang mengalaminya. Varcarolis (2010) menyatakan bahwa individu yang dalam rentang kehidupannya memiliki pikiran positif terhadap kejadian dalam hidupnya akan mengembangkan respon emosi yang positif. Begitu juga sebaliknya, individu yang memiliki pikiran negatif terhadap suatu kejadian yang dialami akan selalu menggunakan pikiran negatif dan irasional bila stressor muncul. Hal inilah yang akan berdampak pada kesehatan jasmani dan psikis (Keliat et al., 2011) salah satunya neurosa.

Neurosa merupakan reaksi psikis dengan ciri khas kecemasan yang secara tidak sadar ditampilkan dalam berbagai bentuk tingkah laku. Kecemasan dapat menyebabkan ketidakseimbangan fisik misalnya peningkatan tekanan darah, insomnia, ketegangan otot dan palpitasi. Sedangkan ketidakseimbangan psikologis yang dapat muncul misalnya sulit berkonsentrasi, bingung, kehilangan kontrol dan ketidakseimbangan sosial (Stuart, 2007).

Berdasarkan hasil riset kesehatan dasar (Riskesdas) penduduk Indonesia tahun 2013, prevalensi gangguan emosional sebanyak $(6 \%)$ sedangkan prevalensi gangguan jiwa berat 1.7 per mi. Diantara berbagai gangguan jiwa, gangguan neurosa (neurosis cemas) merupakan gangguan jiwa yang paling banyak didapati dimasyarakat yaitu 2-4\% (Hawari, 2001). Di Kota Blitar sendiri khususnya di wilayah kerja Puskesmas Kepanjen Kidul Kota Blitar ada 35 klien dengan diagnosa neurosa yang berkunjung setiap bulannya, dan belum pernah ada intervensi lanjutan untuk menanganinya.

Prevalensi kecemasan meningkat sejalan dengan perjalanan penyakit dan gejala (Spiegel \& Darwis, 2003). Kecemasan memiliki dua aspek yaitu aspek sehat dan aspek yang membahayakan dimana hal tersebut tergantung pada tingkat ansietas, lama ansietas yang dialami dan koping individu. Kecemasan dapat memberikan tanda dan gejala yang berupa keluhan-keluhan yang diungkapkan secara subyektif ataupun yang dapat diamati dengan observasi yang terdiri dari aspek fisik, aspek kognitif, psikologis sosial dan perilaku. Manifestasi klinis yang ditunjukkan seperti kelelahan, tidak dapat beristirahat, tidak dapat berkonsentrasi, mudah terangsang, ketegangan meningkat, dan kehilangan kontrol yang dapat dialami klien sepanjang masa sakitnya. Ketegangan otot dan kesulitan tidur adalah respon kecemasan yang sering dialami klien. Menurut Colten \& Altevogt (2006) terdapat beberapa faktor yang dapat mempengaruhi tidur seperti faktor fisik, psikologis, sosial dan lingkungan. Adanya perubahan pada aspek fisik, psikologis, sosial dan lingkungan mengakibatkan berkurangnya waktu tidur.

Psikoterapi menjadi lebih efektif jika dibandingkan terapi medis dalam evaluasi jangka panjang. Hal ini dimungkinkan terjadi karena psikoterapi bertujuan untuk membantu pasien atau keluarga merubah pola kognitif, perilaku yang didasari pemahaman mendalam mengenai masalah yang dialami oleh pasien serta keluarganya (Iyus, 2007).

Beberapa psikoterapi yang dapat diberikan pada klien kecemasan adalah terapi individu seperti terapi kognitif, terapi perilaku, thought stopping, terapi relaksasi otot progresif, terapi kognitif perilaku serta logoterapi individu. Terapi relaksasi otot progresif dapat diterapkan pada klien neurosa dengan kecemasan. Sebelum terapi relaksasi otot progresif ini diberikan, terlebih dahulu dilakukan terapi relaksasi nafas dalam sebagai terapi dasar. Dimana terapi relaksasi nafas dalam merupakan suatu bentuk asuhan keperawatan dimana perawat mengajarkan bagaimana cara melakukan nafas dalam, nafas lambat (menahan inspirasi secara maksimal) dan bagaimana menghembuskan nafas secara perlahan. Latihan ini dapat menurunkan konsumsi oksigen, frekuensi pernafasan, frekuensi jantung, dan ketegangan otot yang dapat menghentikan ansietas dan ketegangan otot.

Latihan relaksasi bertujuan untuk membedakan perasaan yang dialami saat kelompok otot dilemaskan dan dibandingkan ketika otot-otot dalam kondisi tegang. Dengan mengetahui lokasi dan merasakan otot yang tegang maka klien dapat merasakan hilangnya ketegangan sebagai salah satu respon ansietas 
dengan lebih jelas dimana terapi relaksasi otot progresif dapat merangsang pengeluaran zat kimia endorfin dan enkefalin serta merangsang signal otak yang menyebabkan otot rileks dan meningkatkan aliran darah ke otak. Relaksasi otot progresif dapat membuat pikiran terasa tenang, rileks dan lebih mudah untuk tidur (Conrad \& Roth, 2007).

Di indonesia penelitian tentang relaksasi sudah banyak dilakukan. Hal ini didukung oleh beberapa penelitian terkait dengan terapi relaksasi otot progresif diantaranya Jeong le et al., (2012) bahwa terapi musik dan terapi relaksasi otot progresif dapat menurunkan kecemasan pasien yang menjalani perawatan selama kemoterapi kanker. Selain itu menurut Tobing (2012) didapatkan hasil bahwa terapi relaksasi otot progresif dan logoterapi direkomendasikan sebagai terapi keperawatan lanjutan dalam merawat klien kanker dengan kecemasan dan depresi.

Seperti yang telah dijelaskan bahwa kecemasan mencetuskan beberapa sensasi dan perubahan fisik diantaranya peningkatan aliran darah menuju otot, ketegangan otot, mempercepat dan memperlambat pernafasan, meningkatkan denyut jantung dan menurunkan fungsi digestif. Jika terapi lanjutan yaitu terapi relaksasi otot progresif tidak diberikan maka jalur umpan balik yang bekerja dengan mengaktivasi kerja sistem saraf parasimpatik dan memanipulasi hipotalamus melalui pemusatan pikiran tidak dapat dihambat akibatnya sikap positif terhadap rangsangan stress pada hipotamus tidak dapat berkurang (Copstead \& Banasik, 2000) yang dapat mengarahkan individu jatuh pada kondisi gangguan.

Penanganan masalah psikososial dapat dilakukan dengan pemberian terapi modalitas. Berdasarkan uraian dan hasil temuan penelitian yang ada, maka peneliti tertarik untuk menerapkan terapi relaksasi otot progresif terhadap klien dengan neurosa yang mengalami kecemasan dan gangguan tidur di wilayah kerja Puskesmas Kepanjen Kidul Kota Blitar.

\section{BAHAN DAN METODE}

Penelitian ini merupakan jenis penelitian kuantitatif dengan desain Quasy Eksperimental Pre-Post Test With Control Group. Populasi dalam penelitian ini adalah seluruh pasien neurosa di Wilayah Kerja Puskesmas Kepanjen
Kidul Kota Blitar sebanyak 35 orang. Tehnik pengambilan sampel yang digunakan dalam penelitian ini adalah purposive sampling, dengan jumlah sampel yang didapatkan 26 responden. Setelah diperoleh sampel selanjutnya dilakukan simple random sampling untuk membagi sampel menjadi kelompok perlakuan sebanyak 13 responden dan kelompok kontrol 13 responden.

Instrumen yang digunakan untuk mengukuran kecemasan menggunakan kuesioner HAR-S sedangkan instrumen yang digunakan untuk mengukur kualitas tidur dengan menggunakan kuesioner PSQI (The Pittsburgh Sleep Quality Index). Dalam pelaksanaan penelitian total membutuhkan waktu 6 minggu. 5 minggu digunakan untuk pelaksanaan terapi baik pada kelompok perlakuan maupun kelompok kontroL, dan satu minggu digunakan untuk evaluasi kecemasan dan kualitas tidur setelah dilakukan terapi

Analisa ini digunakan dalam penelitian ini terdiri dari analisis bivariat dan univariat. Dalam ananlisi univariat dengan menggunakan uji statistik Paired t-test yang bertujuan untuk menguji perubahan kecemasan dan kualitas tidur sebelum dan sesudah pemberian terapi pada kelompok kontrol dan perlakuan. Sedangkan untuk membandingkan hasil post test perubahan kecemasan dan kualitas tidur pada kelompok perlakuan dan kontrol digunakan analisis data dengan Independen $t$ test. Untuk melihat hubungan antara kecemasan dan kualitas tidur pasien neurosa yaitu dengan menggunakan Pearson.

\section{HASIL PENELITIAN}

Tabel 1. Karakteristik Responden Berdasarkan Usia $(\mathrm{n}$ perlakuan $=13, \mathrm{n}$ kontrol $=13)$

\begin{tabular}{lccccc}
\hline \multicolumn{1}{c}{ Variabel } & Mean & SD & Min & Mak & $\begin{array}{c}\text { P } \\
\text { value }\end{array}$ \\
\hline $\begin{array}{l}\text { Usia (tahun) } \\
\begin{array}{l}\text { Kelompok } \\
\text { perlakuan }\end{array}\end{array}$ & 45,15 & 9,998 & 31 & 58 & \\
$\begin{array}{l}\text { Kelompok } \\
\text { kontrol }\end{array}$ & 45,46 & 12,19 & 18 & 60 & 0,948 \\
\hline
\end{tabular}

Tabel 2. Karakteristik dan uji kesetaraan responden berdasarkan jenis kelamin, pekerjaan, pendidikan, dan status perkawinan

$(\mathrm{n}$ perlakuan $=13, \mathrm{n}$ kontrol $=13)$

\begin{tabular}{ccccccc}
\hline Variabel & Kategori & \multicolumn{2}{c}{$\begin{array}{c}\text { Kel. } \\
\text { perlakuan }\end{array}$} & Kel. kontrol & $\begin{array}{c}\mathbf{P} \\
\text { value }\end{array}$ \\
\hline & & n & \% & n & \% & \\
\hline Jenis & Laki-laki & 6 & 42,9 & 4 & 30,8 & 0,853 \\
\hline
\end{tabular}




\begin{tabular}{llccccc}
\hline Variabel & Kategori & \multicolumn{2}{c}{$\begin{array}{c}\text { Kel. } \\
\text { perlakuan }\end{array}$} & Kel. kontrol & $\begin{array}{c}\text { P } \\
\text { value }\end{array}$ \\
\hline & & n & \% & n & \% & \\
\hline Kelamin & Perempuan & 7 & 53,8 & 9 & 69,2 & \\
\hline Pekerjaan & Swasta & 6 & 42,9 & 6 & 46,2 & 0,700 \\
& Petani & 1 & 7,1 & 6 & 46,2 & \\
& IRT & 5 & 35,7 & 1 & 7,7 & \\
& Tidak bekerja & 1 & 7,1 & & & \\
\hline Status & Menikah & 11 & 78,6 & 11 & 78,6 & 0,512 \\
Perkawinan & Belum & 2 & 14,3 & 2 & 14,3 & \\
& menikah & & & & & \\
\hline Pendidkan & SD & 3 & 21,4 & 3 & 23,1 & 0,156 \\
& SMP & 6 & 42,9 & 5 & 38,5 & \\
& SMA & 4 & 28,6 & 5 & 38,5 & \\
\hline
\end{tabular}

Tabel 3 Distribusi Kecemasan pada Kelompok Perlakuan dan kontrol sebelum dan sesudah diberikan intervensi di Wilayah Kerja Puskesmas Kepanjen Kidul Kota Blitar Tahun 2015

\begin{tabular}{|c|c|c|c|c|c|c|}
\hline Kelompok & Interv & $\mathrm{N}$ & Mean & SD & $\begin{array}{l}\text { Min- } \\
\text { Max }\end{array}$ & $\begin{array}{c}95 \% \\
\text { CI } \\
\end{array}$ \\
\hline \multirow[t]{2}{*}{ Perlakuan } & Pre & 13 & 94,31 & 9,970 & $79-117$ & $88,28-$ \\
\hline & Post & 13 & 67,38 & 12,593 & $47-87$ & $\begin{array}{l}10,933 \\
59,79 \text { bel } \\
74,99\end{array}$ \\
\hline \multirow[t]{2}{*}{ Kontrol } & Pre & 13 & 91,62 & 10,681 & $78-114$ & $\begin{array}{l}85,16- \\
98,07\end{array}$ \\
\hline & Post & 13 & 83,77 & 14,681 & $63-114$ & $\begin{array}{l}74,90- \\
92,64\end{array}$ \\
\hline
\end{tabular}

Tabel 4 Sebaran data kecemasan pasien neurosa pada Kelompok Perlakuan sebelum dan sesudah diberikan terapi relaksasi otot progresif dan kelompok kontrol yang diberikan nafas dalam

\begin{tabular}{lccc}
\hline \multicolumn{1}{c}{ Kelompok } & $\mathrm{N}$ & Parameter & p value \\
\hline Perlakuan (Pre) & 13 & Shapiro-wilk & 0,761 \\
Perlakuan (Post) & 13 & Shapiro-wilk & 0,616 \\
Kontrol (Pre) & 13 & Shapiro-wilk & 0,466 \\
Kontrol (Post) & 13 & Shapiro-wilk & 0,675 \\
Perlakuan + & 26 & Shapiro-wilk & 0,271 \\
Kontrol (Pre) & & & \\
Perlakuan + & 26 & Shapiro-wilk & 0,764 \\
Kontrol (Post) & & & \\
\hline
\end{tabular}

Hasil analisis sebaran data kecemasan pasien neurosa sebelum dan sesudah pada kelompok perlakuan yang diberikan terapi relaksasi otot progresif dan kelompok kontrol yang diberikan nafas dalam didapatkan sebaran normal dengan $\mathrm{p}>0,05$. Analisis data kecemasan pasien neurosa sebelum dan sesudah intervensi pada kelompok perlakuan yang diberikan terapi relaksasi otot progresif dan kelompok kontrol yang diberikan nafas dapat dilihat pada Gambar 1 2

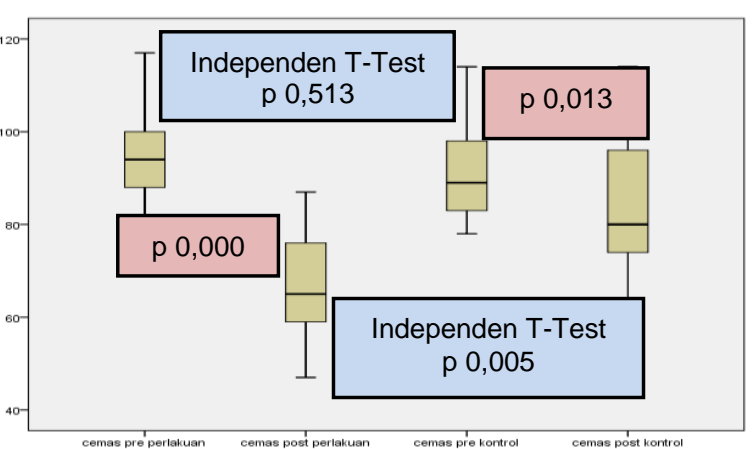

Gambar 1 Kecemasan pasien neurosa pada Kelompok Perlakuan dan kontro sebelum dan sesudah diberikan terapi relaksasi otot progresif dan kelompok kontrol yang diberikan nafas dalam di Wilayah Kerja Puskesmas Kepanjen Kidul Kota Blitar Tahun 2015

Sebaran data kualitas tidur pasien neurosa pada Kelompok Perlakuan dan kontrol sebelum dan sesudah diberikan terapi relaksasi otot progresif dan kelompok kontrol yang diberikan nafas dalam

\begin{tabular}{lccc}
\hline \multicolumn{1}{c}{ Kelompok } & $\mathrm{N}$ & Parameter & p value \\
\hline Perlakuan (Pre) & 13 & Shapiro-wilk & 0,077 \\
Perlakuan (Post) & 13 & Shapiro-wilk & 0,060 \\
Kontrol (Pre) & 13 & Shapiro-wilk & 0,437 \\
Kontrol (Post) & 13 & Shapiro-wilk & 0,297 \\
Perlakuan + Kontrol (Pre) & 26 & Shapiro-wilk & 0,012 \\
Perlakuan + Kontrol & 26 & Shapiro-wilk & 0,261 \\
(Post) & & & \\
\hline
\end{tabular}

Hasil analisis sebaran data kualitas tidur pasien neurosa sebelum dan sesudah pada kelompok perlakuan yang diberikan terapi relaksasi otot progresif dan kelompok kontrol yang diberikan nafas dalam didapatkan sebaran normal dengan $p>0,05$. Analisis data kualitas tidur pasien neurosa sebelum dan sesudah pada kelompok perlakuan yang diberikan terapi relaksasi otot progresif dan kelompok kontrol yang diberikan nafas dapat dilihat pada Gambar

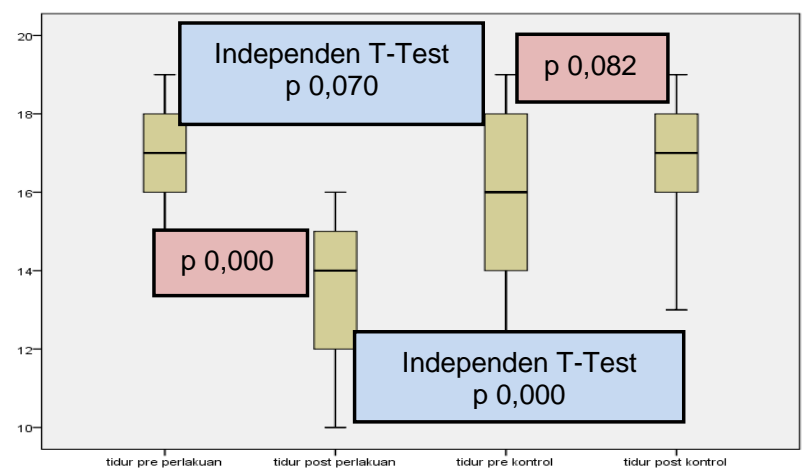


Gambar 2 Kualitas tidur pasien neurosa pada Kelompok Perlakuan sebelum dan sesudah diberikan terapi relaksasi otot progresif dan kelompok kontrol yang diberikan nafas dalam di Wilayah Kerja Puskesmas Kepanjen Kidul Kota Blitar Tahun 2015

Tabel 6 Hubungan Kecemasan dengan kualitas tidur pasien neurosa di Wilayah Kerja Puskesmas Kepanjen Kidul Kota Blitar Tahun 2015

\begin{tabular}{ccc}
\hline Variabel & $\mathrm{r}$ & $\mathrm{p}$ value \\
\hline $\begin{array}{c}\text { Kecemasan dengan kualitas tidur pasien } \\
\text { neurosa sebelum diberikan terapi }\end{array}$ & $-0,043$ & 0,836 \\
\hline $\begin{array}{c}\text { Kecemasan dengan kualitas tidur pasien } \\
\text { neurosa sesudah sebelum diberikan terapi }\end{array}$ & 0,281 & 0,165 \\
\hline
\end{tabular}

\section{PEMBAHASAN}

Kecemasan pasien neurosa sebelum dan sesudah diberikan terapi relaksasi otot progresif pada kelompok perlakuan di Wilayah Kerja Puskesmas Kepanjen Kidul Kota Blitar.

Hasil penelitian menunjukkan bahwa terdapat perbedaan skor kecemasan pasien neurosa pada kelompok perlakuan sebelum dan setelah diberikan relaksasi otot progresif dengan $\mathrm{p} 0,000(\mathrm{p}<0,05)$.

Terapi relaksasi otot progresif merupakan salah satu intervensi keperawatan yang terbukti efektif untuk mengurangi ansietas dimana berkurangnya kecemasan akan mempengaruhi berbagai gejala fisiologis dan psikologis seseorang. Stuart \& Laraia (2005) menjelaskan bahwa seseorang yang mengalami kecemasan akan mengakibatkan ketidakseimbangan dari segi fisik seperti tanda-tanda vital, gangguan pola makan, pola tidur dan adanya ketegangan otot. Dalam hal ini relaksasi otot progresif bermanfaat untuk menghambat jalur umpan balik dengan cara mengaktivasi kerja sistem saraf parasimpatik dan memanipulasi hipotalamus melalui pemusatan pikiran untuk memperkuat sikap positif sehingga rangsangan stress terhadap hipotamus berkurang (Copstead \& Banasik, 2000). Hal ini sesuai dengan penelitian yang telah dilakukan oleh Jeong Lee, Bhattachary et al (2012) bahwa relaksasi otot progresif efektif untuk relaksasi dan munurunkan ansietas pada pasien yang menjalani kemoterapi.
Dalam pelaksanaannya, terapi ini dilakukan secara individu yang bertempat dirumah masing-masing pasien neurosa. Kondisi tersebut memungkinkan pasien untuk mendapat posisi yang nyaman saat dilakukan terapi dan dapat berkonsentrasi karena lingkungan yang tenang. Lama terapi 30-45 menit 1 kali seminggu selama 5 minggu. Hal tersebut sesuai dengan pendapat Gift, 1992; Peck 1997 dalam Synder \& Lynquist (2002) bahwa elemen penting yang diperlukan untuk membuat rileks yaitu lingkungan yang tenang, posisi yang nyaman, sikap yang baik. Untuk hasil yang maksimal dianjurkan dilakukan secara rutin selama 25- 30 menit. Agee, Burg \& Grant, (2008) dalam penelitiannya menyatakan bahwa gerakan yang dilakukan pada relaksasi otot progresif sebanyak $1 \mathrm{kali} /$ minggu selama 5 minggu dapat menurunkan kecemasan.

Neurosa merupakan reaksi psikis dengan gejalanya yaitu kecemasan yang secara tidak sadar ditampilkan dalam berbagai bentuk tingkah laku, hal ini dilatarbelakangi oleh tekanan emosi, konflik dan frustasi. Kecemasan yang dirasakan secara langsung diubah oleh berbagai mekanisme pertahanan psikologis dan kemudian muncullah gejala-gejala subjektif yang mengganggu (Verhaeghe \& Vanheule, 2005). Menurut (Videbeck (2008) \& Stuart (2009) kecemasan merupakan kekhawatiran yang tidak jelas yang berkaitan dengan perasaan tidak pasti dan tidak berdaya.

Terapi relaksasi otot progresif yang dilakukan yaitu 3 sesi secara langsung dalam satu kali pertemuan. Pada sesi satu yaitu mengidentifikasi ketegangan otot yang dirasakan, dilanjutkan ke sesi dua yaitu pelaksanaan relaksasi otot dengan 14 gerakan dan sesi yang ketiga yaitu evaluasi hasil terapi. Gerakan yang dilakukan yaitu dengan mengencangkan dan melemaskan otot-otot pada satu bagian tubuh pada satu waktu. Gerakan mengencangkan dan melemaskan otot ini dilakukan secara berturut-turut dan perhatian klien diarahkan untuk membedakan perasaan yang dialami saat kelompok otot dilemaskan dan dibandingkan ketika otot-otot dalam kondisi tegang.

Hal ini sesuai dengan penelitian Ramdhani (2008) bahwa relaksasi otot progresif merupakan bagian dari terapi relaksasi yang terdiri dari 3 sesi. Terapi ini digunakan sebagai suatu ketrampilan koping yang mengajarkan 
klien kapan dan bagaimana melakukan relaksasi dan kenyamanan di bawah kondisi yang dapat menimbulkan kecemasan. Terapi ini dilakukan dengan gerakan mengencangkan dan melemaskan otot-otot pada satu bagian tubuh dalam satu waktu untuk memberikan perasaan relaksasi secara fisik. Dengan mengetahui lokasi dan merasakan otot yang tegang maka klien dapat merasakan hilangnya ketegangan sebagai salah satu respon kecemasan. Terapi relaksasi otot progresif akan merangsang pengeluaran zat kimia endorphin dan enkefalin serta merangsang signal otak yang dapat menyebabkan otot rileks dan meningkatkan aliran darah ke otak sehingga dapat membuat pikiran terasa tenang dan rileks.

Dalam penelitian ini jenis kelamin responden rata-rata pada kelompok perlakuan adalah perempuan. Kaplan dan Saddock (2005) menyatakan bahwa perempuan 2-3 kali lebih mudah mengalami kecemasan dibandingkan laki-laki, hal ini dikarenakan perempuan lebih mendahulukan emosi. Sehingga pada saat mengalami stres, aspek emosilah yang lebih tersentuh yang berdampak pada kondisi kesehatannya. Selain jenis kelamin, pekerjaan juga merupakan sumber eksternal yang dapat mencetuskan timbulnya kecemasan (Suliswati, 2005). Hal ini juga sesuai dengan hasil penelitian bahwa rata-rata responden bekerja swasta. Pekerjaan berkaitan dengan status ekonomi yang dimiliki yang akan mempengaruhi munculnya stres yang lebih lanjut dapat mencetuskan kecemasan. Hal ini sesuai dengan penelitian Tarwoto dan Wartonah (2008), bahwa terdapat beberapa hal yang dapat mempengaruhi kecemasan diantaranya maturitas individu, tipe kepribadian dan pendidikan.

Terapi relaksasi otot progresif merupakan salah satu bentuk terapi relaksasi yang dapat diberikan pada pasien yang mengalami ansietas dengan manifestasi adanya ketegangan otot. Pada relaksasi otot progresif kontraksi otot akan diikuti dengan relaksasi pada 14 kelompok otot (Berstein \& Borkovec, 1973 dalam Kwekkeboom \& Gretarsdottir, 2006 ; Conrad \& Roth, 2007; Supriati, 2010, Alini, 2012). Latihan relaksasi otot progresif yang rutin akan meningkatkan kemampuan klien untuk melakukan relaksasi yang nantinya akan berkontribusi terhadap penurunan kecemasan.

\section{Kualitas tidur pasien neurosa sebelum dan sesudah diberikan terapi relaksasi otot progresif pada kelompok perlakuan di Wilayah Kerja Puskesmas Kepanjen Kidul Kota Blitar.}

Hasil penelitian menunjukkan bahwa terdapat perbedaan skor kualitas tidur pasien neurosa pada kelompok perlakuan sebelum dan setelah diberikan intervensi dengan p 0,000 $(\alpha<0,05)$.

Dalam penelitian didapatkan hasil bahwa relaksasi otot progresif menunjukkan manfaat dalam mengurangi ketegangan dan ansietas, pasien yang berkonsentrasi penuh saat melakukan terapi merasakan rileksasi maksimal yang membuat pasien tertidur.

Hal ini sesuai dengan penelitian Prayitno (2002) bahwa terapi yang dilakukan dengan baik dan penuh dengan konsentrasi akan memperbaiki berbagai gejala fisiologis dan psikologis seseorang karena dapat menciptakan keadaan yang rileks dan efektif dalam memperbaiki tidur. Pendapat lain juga dikemukakan oleh Widastra (2009) bahwa beberapa teknik yang dapat dilakukan untuk meningkatkan kebutuhan tidur secara kualitas dan kuantitas adalah metode bootzin dan metode relaksasi, namun pendekatan relaksasi yang paling banyak digunakan adalah relaksasi otot progresif.

Dalam penelitian didapatkan rata-rata pasien mempunyai kualitas tidur yang tidak baik karena beban psikologis yang dirasakan misalnya kondisi keluarga, hubungan dengan anggota keluarga, kenakalan anak, hubungan dengan pasangan, kehilangan orang yang dicintai dan sebagainya. Hal inilah yang membuat pasien susah untuk memulai tidur, mudah terbangun saat malam hari dan tidak mendapatkan kualitas tidur yang baik. Hal ini sesuai dengan teori dari Stuart \& Laraia (2005) yang menjelaskan bahwa seseorang yang mengalami kecemasan akan mengakibatkan ketidakseimbangan dari segi fisik seperti tandatanda vital, gangguan pola makan, pola tidur dan adanya ketegangan otot.

Relaksasi otot progresif didasari pada mekanisme kerja relaksasi otot progresif dalam mempengaruhi kebutuhan tidur, dimana terjadi respon relaksasi (Trophotropic) yang menstimulasi semua fungsi dimana kerjanya berlawanan dengan system saraf simpatis sehingga tercapai keadaan rileks dan tenang. Perasaan rileks ini akan diteruskan ke 
hipotalamus untuk menghasilkan Corticotropin Releasing Factor (CRF) yang nantinya akan menstimulasi kelenjar pituitary untuk meningkatkan produksi beberapa hormone, seperti $\beta$-Endorphin, Enkefalin dan Serotonin (Ramdhani, 2008). Respon relaksasi terjadi karena terangsangnya aktifitas sistem saraf otonom parasimpatis nuclei rafe sehingga menyebabkan perubahan yang dapat mengontrol aktivitas sistem saraf otonom berupa pengurangan fungsi oksigen, frekuensi nafas, denyut nadi, ketegangan otot, tekanan darah, serta gelombang alfa dalam otak sehingga mudah untuk tertidur (Guyton dan Hall, 2000). Selain itu menurut McCloughan, Hanrahan, Anderson et al (2014) relaksasi otot progresif merupakan terapi alternatif untuk memenuhi kebutuhan tidur pasien.

Tidur merupakan salah satu kebutuhan dasar yang berhubungan dengan pemeliharaan dan pemulihan kesehatan yang memungkinkan tubuh dan pikiran tetap berfungsi optimal. Selama periode tidur otak akan mengolah memori jangka panjang, mengintegrasikan informasi yang baru serta memperbaiki jaringan otak dan sel saraf serta berperan dalam proses biokimia. Kualitas tidur yang kurang sangat merugikan dan mempengaruhi kesejahteraan yang berdampak negatif terhadap fungsi fisiologis, psikologis dan pekerjaan seseorang(Riegel \& Weaver, 2009). Relaksasi otot progresif dapat membuat pikiran terasa tenang, rileks dan lebih mudah untuk tidur (Conrad \& Roth, 2007).

Kecemasan pasien neurosa sebelum dan sesudah diberikan terapi nafas dalam pada kelompok kontrol di Wilayah Kerja Puskesmas Kepanjen Kidul Kota Blitar.

Hasil penelitian menunjukkan bahwa terdapat perbedaan skor kecemasan pasien neurosa pada kelompok kontrol sebelum dan sesudah diberikan intervensi nafas dalam dengan nilai $p 0.013(\alpha<0,05)$.

Dalam penelitian ini antara kelompok kontrol dan perlakuan pasien neurosa samasama dilakukan terapi selama 5 minggu, bentuk tindakan yang dilakukan pada kelompok kontrol ini yaitu mengajarkan bagaimana cara melakukan nafas dalam, nafas lambat (menahan inspirasi secara maksimal) dengan irama konstan dan bagaimana menghembuskan nafas secara perlahan. Selain itu pasien diminta untuk berkonsentrasi dengan baik saat melakukan nafas dalam ini, sehingga akan memberikan kenyamanan pada pasien yang berdampak pada penurunan kecemasan yang dirasakan.

Hal ini sesuai dengan teori dari Synder \& Lindquist (2002) yang menyatakan bahwa nafas dalam merupakan salah satu teknik di dalam terapi perilaku yang mengembangkan metode fisiologis untuk melawan ketegangan dan kecemasan. Nafas dalam ini dilakukan dengan frekuensi lambat dan berirama, juga dilakukan dengan cara memejamkan mata dan bernafas secara perlahan dan nyaman. Irama yang konstan dapat dipertahankan dengan menghitung dalam hati dan lambat bersama setiap inhalasi dan ekshalasi. Latihan ini dapat menurunkan konsumsi oksigen, frekuensi pernafasan, frekuensi jantung, dan ketegangan otot yang dapat menghentikan kecemasan.

Teknik relaksasi nafas dalam dipercaya juga mampu merangsang tubuh untuk melepaskan endogen yaitu endorphin dan enkefalin (Smeltzer \& Bare, 2002) yang dapat memberikan rasa nyaman selain itu relaksasi yang dilakukan juga dapat mengakibatkan vasodilatasi pembuluh darah yang akan meningkatkan aliran darah ke daerah yang mengalami spasme.

\section{Kualitas tidur pasien neurosa sebelum dan sesudah diberikan terapi nafas dalam pada kelompok kontrol di Wilayah Kerja Puskesmas Kepanjen Kidul Kota Blitar.}

Hasil penelitian menunjukkan bahwa tidak terdapat perbedaan kualitas tidur pasien neurosa pada kelompok kontrol sebelum dan sesudah diberikan intervensi berupa nafas dalam dengan nilai p $0.82(\alpha<0,05)$.

Nafas dalam merupakan teknik relaksasi sederhana yang terdiri atas nafas dalam dengan frekuensi lambat, dan berirama. Klien dapat memejamkan matanya dan bernafas dengan perlahan dan nyaman. Irama yang konstan dapat dipertahankan dengan menghitung dalam hati dan lambat bersama setiap inhalasi dan ekshalasi (Synder \& Lindquist, 2002).

Smeltzer \& Bare (2002) menyatakan bahwa tujuan teknik relaksasi napas dalam adalah untuk meningkatkan ventilasi alveoli, memelihara pertukaran gas, mencegah atelektasi paru, meningkatkan efesiensi batuk, mengurangi stress baik stress fisik maupun 
emosional yaitu menurunkan intensitas nyeri dan menurunkan kecemasan.

Perbedaan kecemasan pasien neurosa sesudah diberikan terapi relaksasi otot progresif (kelompok perlakuan) dan nafas dalam (kelompok kontrol) di Wilayah Kerja Puskesmas Kepanjen Kidul Kota Blitar.

Hasil penelitian menunjukkan bahwa terdapat perbedaan skor kecemasan pasien neurosa antara kelompok perlakuan dan kelompok kontrol setelah diberikan intervensi dengan nilai $p 0,005$ dimana $p<0,05$.

Respon fisiologis terjadinya ansietas merefleksikan interaksi beberapa neuroendokrin/neurotransmitter serta melibatkan struktur anatomi didalam otak (Fontaine, 2009). Respon fisiologis fight or fight pada saat seseorang mengalami kejadian potensial berbahaya maka akan terjadi respon sistem saraf simpatis yang akan meningkatkan aktivasi kelenjar adrenal. Respon ini mengaktivasi sistem saraf untuk memacu aliran darah ke otot-otot skelet. Hal ini juga didukung dengan pendapat dari center for clinical intervention (2008) yang mengatakan bahwa aktivasi sistem saraf sebagai persiapan kejadian berbahaya oleh tubuh juga akan bermanifestasi sebagai ketegangan otot sebagai salah satu tanda fisiologis yang paling sering dari ansietas.

Pada penelitian ini kelompok perlakuan mendapatkan terapi relaksasi otot progresif yang terdiri dari 3 sesi dimana 3 sesi langsung dilakukan dalam satu kali kunjungan. Terapi relaksasi otot progresif merupakan salah satu bentuk terapi relaksasi yang dapat diberikan pada pasien yang mengalami ansietas dengan manifestasi adanya ketegangan otot. Rangkaian sesi tersebut diantaranya adalah mengidentifikasi ketegangan otot-otot tertentu yang dirasakan oleh pasien, melaksanakan tehnik relaksasi pada 14 kelompok otot meliputi tangan, tangan bagian belakang, otot-otot bisep, otot bahu, otot dahi, otot mata, otot mulut, otot rahang, otot leher belakang, otot leher depan, otot punggung, otot dada, otot perut dan otot paha. Pada sesi ketiga yaitu mengevaluasi kemampuan klien dalam melakukan latihan relaksasi progresif. Evaluasi dilakukan setiap selesai melakukan terapi utnuk menilai kemampuan dan pemahaman pasien dalam melakukan tahapan relaksasi otot, apakah sudah mampu melakukannya secara benar atau belum.
Hal ini sudah sesuai dengan penelitian bahwa pelaksanann relaksasi otot progresif dapat dilakukan 4 sesi dengan melakukan kontraksi otot yang diikuti dengan relaksasi otot pada 14 kelompok otot yaitu tangan dan lengan, bisep, dahi, pipi atas dan hidung, pipi bawah dan rahang, leher dan tenggorokan, dada dengan bahu dan punggung atas, perut, paha, betis dan kaki (Berstein \& Borkovec, 1973 dalam Kwekkeboom \& Gretarsdottir, 2006 ; Conrad \& Roth, 2007; Supriati, 2010, Alini, 2012). Dalam hal ini relaksasi otot progresif bermanfaat untuk menghambat jalur umpan balik dengan cara mengaktivasi kerja sistem saraf parasimpatik dan memanipulasi hipotalamus melalui pemusatan pikiran untuk memperkuat sikap positif sehingga rangsangan stress terhadap hipotamus berkurang (Frisch \& Frisch, 2006).

Untuk kelompok kontrol diberikan relaksasi nafas dalam yaitu mengajarkan bagaimana cara melakukan nafas dalam, nafas lambat (menahan inspirasi secara maksimal) dengan irama konstan dan bagaimana menghembuskan nafas secara perlahan. Selain itu pasien diminta untuk berkonsentrasi dengan baik saat melakukan nafas dalam ini, sehingga akan memberikan kenyamanan pada pasien yang berdampak pada penurunan kecemasan yang dirasakan.

Hal ini sesuai dengan teori dari Synder \& Lindquist (2002) yang menyatakan bahwa irama yang konstan saat nafas dalam dapat dipertahankan dengan menghitung dalam hati dan lambat bersama setiap inhalasi dan ekshalasi. Latihan ini dapat menurunkan konsumsi oksigen, frekuensi pernafasan, frekuensi jantung, dan ketegangan otot yang dapat menghentikan kecemasan.

Kusumawati \& Hartono (2010) memaparkan bahwa ketegangan dalam kehidupan yang dapat menyebabkan kecemasan diantaranya adalah peristiwa traumatik individu baik krisis perkembangan maupun situasional seperti peristiwa bencana, konflik emosional individu yang tidak terselesaikan dengan baik, konsep diri yang terganggu yang akan dapat menimbulkan ketidakmampuan individu berfikir secara realistis, frustasi atau rasa ketidakberdayaaan untuk mengambil keputusan yang berdampak terhadap ego serta pola meknisme koping keluarga atau pola keluarga menangani stress yang akan mempengaruhi individu dalam berespon terhadap konflik. 
Perbedaan kualitas tidur pasien neurosa sesudah diberikan terapi relaksasi otot progresif (kelompok perlakuan) dan nafas dalam (kelompok kontrol) di Wilayah Kerja Puskesmas Kepanjen Kidul Kota Blitar.

Hasil penelitian menunjukkan bahwa terdapat perbedaan skor kualitas tidur pasien neurosa antara kelompok perlakuan dan kelompok kontrol setelah diberikan intervensi dengan nilai $p 0,000$ dimana $p<0,05$.

Dalam penelitian didapatkan rata-rata pasien mengalami penurunan kualitas tidur dikarenakan kecemasan yang dialami misalnya kondisi keluarga, hubungan dengan anggota keluarga, kenakalan anak, hubungan dengan pasangan, kehilangan orang yang dicintai dan sebagainya. Hal inii sesuai dengan pendapat Kartono (1980) bahwa penyebab neurosa dapat berasal dari individu seperti keterbatasan dan kegagalan individu dalam menghadapi masalahnya. Diperkuat dengan pendapat Stuart \& Laraia (2005) bahwa seseorang yang sering mengalami kecemasan dalam kehidupannya akan mudah mengalami ansietas di kemudian hari.

Terapi relaksasi otot progresif merupakan salah satu bentuk terapi relaksasi yang dapat diberikan pada pasien yang mengalami ansietas dengan manifestasi adanya ketegangan otot. Prosedur untuk mendapatkan relaksasi otot melalui dua langkah yaitu dengan memberikan tegangan pada suatu kelompok otot, menghentikan tegangan tersebut dan memusatkan perhatian terhadap bagaimana otot tersebut menjadi rileks dan ketegangan menghilang (Richmon, 2007). Dampak relaksasi akan menghasilkan efek perasaan tenang dan mengurangi ketegangan.

\section{Hubungan antara kecemasan dengan kualitas tidur pasien neurosa di Wilayah Kerja Puskesmas Kepanjen Kidul Kota Blitar sebelum dan sesudah diberikan intervensi pada kelompok perlakuan dan kelompok kontrol.}

Hasil penelitian menunjukkan tidak ada hubungan yang bermakna antara kecemasan dengan kualitas tidur pasien neurosa dengan nilai $\mathrm{p} 0,165$ ( $\mathrm{p}$ value $<0,05$ ) dan nilai $r=0,281$ yang menunjukkan kekuatan hubungan lemah.

Stuart \& Laraia (2005) menjelaskan bahwa seseorang yang mengalami kecemasan akan mengakibatkan ketidakseimbangan dari segi fisik seperti tanda-tanda vital, gangguan pola makan, pola tidur dan adanya ketegangan otot. Relaksasi otot progresif menunjukkan manfaat dalam mengurangi ketegangan dan ansietas yang akan memperbaiki berbagai gejala fisiologis dan psikologis seseorang. Brown (1997 dalam Synder \& Lindquist, 2002) menyebutkan bahwa respon stres adalah bagian dari jalur umpan balik yang tertutup antara otototot dan pikiran. Penilaian terhadap stressor mengakibatkan ketegangan otot yang mengirimkan stimulus ke otak dan membuat jalur umpan balik. Latihan relaksasi merupakan salah satu teknik pengelolaan diri yang didasarkan pada cara kerja sistem saraf simpatis dan parasimpatis. Relaksasi otot akan menghambat jalur tersebut dengan cara mengaktivasi kerja sistem saraf parasimpatis dan memanipulasi hipotalamus melalui pemusatan pikiran untuk memperkuat sikap positif sehingga rangsangan stres terhadap hipotalamus menjadi minimal.

Prinsip yang mendasari penurunan ketegangan oleh teknik relaksasi terletak pada fisiologi sistem syaraf otonom yang merupakan bagian dari sistem syaraf perifer yang mempertahankan homeostatis lingkungan internal individu. Pada saat terjadi pelepasan mediator kimia seperti bradikinin, prostaglandin dan substansi, akan merangsang syaraf simpatis sehingga menyebabkan vasokostriksi yang akhirnya meningkatkan tonus otot yang menimbulkan berbagai efek seperti spasme otot yang akhirnya menekan pembuluh darah, mengurangi aliran darah dan meningkatkan kecepatan metabolisme otot yang menimbulkan pengiriman impuls nyeri akibat dari ketegangan yang dirasakan.

Secara fisiologis tubuh akan memproduksi endogen untuk menghambat impuls nyeri yang ditimbulkan oleh ketegangan yang dirasakan. Endogen terdiri dari endorfin dan enkefalin, apabila tubuh mengeluarkan substansi-substansi ini maka salah satu efeknya adalah meredakan ketegangan yang dirasakan (Smeltzer \& Bare, 2002).

Respon relaksasi terjadi karena terangsangnya aktifitas sistem saraf otonom parasimpatis nuclei rafe sehingga menyebabkan perubahan yang dapat mengontrol aktivitas sistem saraf otonom berupa pengurangan fungsi oksigen, frekuensi nafas, denyut nadi, ketegangan otot, tekanan darah, serta 
gelombang alfa dalam otak sehingga mudah untuk tertidur (Guyton dan Hall, 2000).

\section{SIMPULAN DAN SARAN Simpulan}

Berdasarkan hasil penelitian, dapat disimpulkan bahwa terdapat pengaruh pemberian terapi relaksasi otot progresif pada kelompok perlakuan dan nafas dalam pada kelompok kontrol terhadap penurunan kecemasan dan peningkatan kualitas tidur pasien neurosa di Wilayah Kerja Puskesmas Kepanjen Kidul Kota Blitar.

\section{Saran}

Bagi perawat psikiatrik dan pemegang program kesehatan jiwa di Puskesmas diharapkan dapat menerapkan terapi relaksasi otot progresif untuk menurunkan kecemasan pasien neurosa.

\section{DAFTAR PUSTAKA}

Arntz, A. 2003. Cognitive therapy versus applied relaxation as treatment of generalized anxiety disorder. Journal Behaviour Research and Therapy, 41 (633-646).

Bussye, D.J., Reynolds, C.F., Monk, T.H et al. (1989). The Pittsburgh Sleep Quality Index (PSQI): A New Instrument for Psychiatric Research and Practice Psychiatry Research, 28 (193-213).

Bephage, G. (2005). Promoting Quality Sleep in Order People: The Nursing Care Role. British Journal Nursing, 14(4).

Badan Penelitian dan Pengembangan Kesehatan Departemen Kesehatan RI. 2007. Laporan Nasional Riset Kesehatan Dasar. www. riskesdas. litbang depkes. go.id. diakses tanggal 2 Februari 2015.

Bebbington, P.E., Brugha, S., Meltzer, $\mathrm{H}$ et al. 2000. Neurotic Disorders and The Receipt of Psychiatric Treatment. Journal Psychological Medicine, 30(1369-1376).

Bush, L.A., Armento, E.A., Weiss.J.B et al. (2012). The Pittsburgh Sleep Quality Index in Older Primary Care Patients With Generalized Anxiety Disorder: Journal Psychometrics and outcomes following cognitive behavioral therapy Psychiatry Research, 199 (24-30). www.elsevier.com/locate/psychres

Colten, R., Harvey., Altevogt, M.B. (2006). Sleep Disorders and Sleep Deprivation:
An Unmet Public Health Problem. Washington, DC: The National Academic Press.

Conrad, A., Roth, W.T. 2007. Muscle Relaxation Therapy for Anxiety Disorders: It Works But How? Journal of Anxiety Disorders, 21 (243-264).

Dogan, O., Ertekin, S., Dogan, S. et al. (2005). Sleep Quality in Hospitalized Patients. Journal of Clinical Nursing, 14 (107113).

Frisch, N.C \& Frisch, L.E. 2006. Psychiatric Mental Health Nursing (3th ed). New York: Thomson Delmar Lerning.

Fontaine, K.L. 2009. Mental Health Nursing (7 th edition). New Jersey: Pearson Education, Inc.

Freeman, D., Garety, P.A. 2003. Connecting Neurosis and Psychosis: The Direct Influence of Emotion on Delusions and Hallucinations. Behaviour Research and Therapy, 41(923-947).

Hardy, S. (2008). A Double Bind: Disturbed Sleep and Depression. Practice Nursing, 9(2).

Judith, T.R., Julie, T.S., and Elizabeth, V.W. (2010). Managing Sleep Disorder in Elderly. Nurse Practitioner, 355 (30-37).

Jeong, L.E., Bhattacharyab, J., Sohnc, C., Verresa, R. 2012. Monochord Sounds and Progressive muscle relaxation reduce Anxiety and Improve Relaxation During Chemotherapy. Journal Complementary Therapies in Medicine, 20(409-416). www.elsevierhealth.com/journals/ctim

Kaplan \& Sadock. 2007. Sinopsis Psikiatri: Ilmu Pengetahuan Psikiatri Klinis Jilid 1. Jakarta: Bina Rupa Aksara

Keliat, B.A, Akemat. 2010. Model Praktik Keperawatan Profesional Jiwa. Jakarta: EGC.

Kusumawati, F, Hartono.Y. 2010. Buku Ajar Keperawatan Jiwa. Jakarta: Salemba Medika

Loriz, L.M. (2004). Excessive Daytime Sleepiness: How to Help Your Patient Manage. Clinical Excelelence for Nursing Practitioners, 8(2).

Langford , D,J., Lee , K., Miaskowski, C. (2012). Sleep Disturbance Interventions in Oncology Patients and Family Caregivers: A Comprehensive Review and Meta-Analysis Sleep Medicine 
Reviews, www.elsevier.com/locate/smrv

Maramis, W.F. 2006. Catatan Ilmu Kedokteran Jiwa. Surabaya: Airlangga University Press.

Notoatmodjo, S. 2010. Metodologi Penelitian Kesehatan. Jakarta: Rineka Cipta.

Nishiyama, T., Mizuno, T., Kojima, M et al. (2014). Criterion Validity of The Pittsburgh Sleep Quality Index and Epworth Sleepiness Scale for The Diagnosis of Sleep Disorders. Journal Sleep Medicine, 15(422-429).

Patlak, M. (2005). Your Guide to Healthy Sleep. U.S. Departement of Health and Human Services: NIH Publication no.065271.

Ramdhani, N \& Putra, A.A. 2008. Pengembangan multimedia relaksasi. Yogyakarta: bagian psikologis klinis fakultas psikologi UGM

Riegel, B., Weaver, T.E. (2009). Poor Sleep and Impaired Self-Care: Toward a Comprehensive Model Linking Sleep, Cognition, and Heart Failure Outcomes. Eur J Cardiovasc Nurs, 5(337-344).

Stuart, G.W \& Laraia, M.T. 2005. Principles and Practice of Psychiatric Nursing (7th edition). St. Louis: Mosby

Stuart, G.W. 2009. Principles and Practice of Psychiatric Nursing (9th edition). St. Louis: Mosby

Tarwoto \& Wartonah. 2003. Kebutuhan Dasar Manusia \& Proses Keperawatan. Edisi pertama. Jakarta: Salemba Medika.

Townsend, C.M. 2005. Essentials of Psychiatric Mental Health Nursing (3th $E d)$. Philadelphia: F.A. Davis Company.

Varcolis, E.M. 2006. Psychiatric nursing clinical guide: assesment tools and diagnosis. Philadelphia. W.B Saunders Co.

Videbeck, S.L. 2008. Buku Ajar Keperawatan Jiwa. Jakarta: EGC

Verhaeghe, P., Vanheule , S. 2005. Actual Neurosis and PTSD. Journal The Impact of the Other Psychoanalytic Psychology, 22 4(493-507).

Wilson, S. (2008). A Good Night"s Sleep, Part One: Normal Sleep. Nursing \& Residential care, 1011

Zhao, L., Wub, H., Zhou, X et al. 2012. Effects of Progressive Muscular Relaxation
Training on Anxiety, Depression and Quality of Life of Endometriosis Patients Under Gonadotrophin-Releasing Hormone Agonist Therapy. European Journal of Obstetrics \& Gynecology and Reproductive Biology, 162(211-215). 
174 Jurnal Ners dan Kebidanan, Volume 2, Nomor 2, Agustus 2015, hlm.163-172 
